\title{
Analisis Keaktifan dan Hasil Belajar Siswa Dengan Menggunakan Model Pembelajaran Flipped Classroom Melalui Aplikasi Zoom Pada Materi Suhu dan Kalor di SMP Negeri 2 Bontang
}

\author{
Putri Hidayati $^{1 \star}$, M. Junus ${ }^{2}$, dan Muliati Syam ${ }^{3}$ \\ $1^{\star}, 2,3$ Program Studi Pendidikan Fisika, FKIP Universitas Mulawarman \\ JI. Muara Pahu Komplek Universitas Mulawarman Gunung Kelua Samarinda \\ *E-mail Penulis Korespondensi: putrihidayatibtg@gmail.com
}

\begin{abstract}
Abstrak
Tujuan penelitian ini yaitu untuk mengetahui keaktifan dan hasil belajar siswa dengan menggunakan model pembelajaran flipped classroom melalui aplikasi zoom. Pengumpulan data menggunakan teknik observasi dan tes berupa 10 butir soal essay untuk mengetahui hasil belajar siswa (posttest). Hasil penelitian menunjukkan bahwa keaktifan siswa pada pertemuan pertama dan kedua termasuk kedalam kriteria keaktifan sedang dengan persentase $57,77 \%$ dan $62 \%$. Kemudian pada pertemuan ketiga termasuk kedalam kriteria keaktifan siswa tinggi dengan persentase $75 \%$. Sedangkan untuk hasil belajar belajar siswa didapatkan nilai n-gain sebesar 0,56 dimana jika dibandingkan dengan tabel kriteria keefektifan, maka nilai n-gain pada penelitian ini termasuk dalam kategor sedang. Untuk kemampuan kognitif pada tingkat mengingat (C1) dan memahami (C2) sudah menunjukan sangat tinggi dengan persentase yang didapatkan yaitu (95\%) dan (98\%). Sedangkan untuk tingkat menerapkan (C3), menganalisis (C4), dan mengevaluasi (C5)masih terbilang cukup karena persentase yang didapatkan yaitu (55\%), $(52 \%)$, dan (52\%).
\end{abstract}

Kata kunci: Flipped Classroom, Keaktifan Siswa, Hasil Belajar Siswa.

\section{Abstract}

The purpose of this study is to determine the activeness and learning outcomes of students by using the flipped classroom learning model through the zoom application. Data collection used observation techniques and tests in the form of 10 essay items to determine student learning outcomes (posttest). The results showed that the activeness of students at the first and second meetings was included in the medium activeness criteria with a percentage of $57.77 \%$ and $62 \%$. Then at the third meeting it was included in the high student activeness criteria with a percentage of $75 \%$. Meanwhile, for student learning outcomes, the $n$-gain value is 0.56 , where when compared with the effectiveness criteria table, the $n$-gain value in this study is included in the medium category. For cognitive abilities at the level of remembering (C1) and understanding (C2) it has shown very well with the percentages obtained, namely (95\%) and (98\%). Meanwhile, the level of applying (C3), analyzing (C4), and evaluating (C5) is still sufficient because the percentages obtained are (55\%), (52\%), and (52\%).

Keywords: Flipped Classroom, Student Activity, Student Learning Outcomes

Article History: Received: 29 October 2021

Accepted: 1 November 2021
Revised : 23 November 2021

Published: 30 November 2021

How to cite: Hidayati, Putri., Junus, M., Syam Muliati (2021). Analisis Keaktifan dan Hasil Belajar Siswa Dengan Menggunakan Model Pembelajaran Flipped Classroom Melalui Aplikasi Zoom Pada Materi Suhu dan Kalor, Jurnal Literasi Pendidikan Fisika, 2 (2). pp. 149-159. Retrieved from http://jurnal.fkip.unmul.ac.id/index.php/JLPF

Copyright (C) November 2021, Jurnal Literasi Pendidikan Fisika 
Analisis Keaktifan dan...

\section{PENDAHULUAN}

Flipped Classroom ditemukan pertama kali oleh Bergmann dan Aaron Sams, ia adalah seorang guru Kimia di Connecticut Amerika Serikat (Galindo, 2014). Flipped Classroom atau biasa disebut kelas terbalik merupakan kegiatan proses belajar mengajar dimana peserta didik mempelajari materi pembelajaran yang diberikan oleh guru berupa video pembelajaran maupun materi sebelum tiba di kelas. Kemudian kegiatan di dalam kelas akan digunakan untuk berdiskusi kelompok untuk memecahkan suatu masalah, meningkatkan konsep, dan saling tanya jawab di dalam kelas. Peserta didik akan mempelajari materi pembelajaran video pembelajaran maupun materi yang telah dikirim beberapa hari sebelum kelas dimulai oleh guru kepada peserta didik melalui media sosial. Guru juga harus menyiapkan langkah-langkah pembelajaran yang harus dipelajari siswa rumah. Sehingga siswa tidak hanya menyimak video pembelajaran, tetapi melakukan kegiatan pembelajaran berdasarkani materi (Indah Utari Akip, 2019).

Menurut data Dinas Pendidikan tahun 2020 platfrom yang paling banyak dimanfaatkan sekolah dan Universitas di Indonesia adalah Zoom Meeting. Zoom Meeting merupakan sebuah media pembelajaran menggunakan video. Pendiri aplikasi Zoom Meeting yaitu Eric Yuan yang diresmikan tahun 2011 yang kantor pusatnya berada di San Jose, California. Platfrom ini gratis jadi dapat digunakan oleh siapapun dengan batas waktu empat puluh menit dan tidak ada batasan waktu jika akun kita berbayar. Dalam aplikasi Zoom Meeting ini kita bisa berkomunikasi langsung dengan siapapun lewat video, oleh karena itu, memang cocok digunakan sebagai media pembelajaran. Pola pembelajaran dengan memberikan materi pembelajaran dan tugas yang sering sekali membuat siswa merasa bosan dalam masa BDR ini. Salah satu model pembelajaran yang cukup bagus untuk dilakukan dalam pembelajaran online ini yaitu model pembelajaran Flipped Classroom (Haqien \& Rahman, 2020).

Flipped classroom adalah pembelajaran yang masih terbilang baru. Pembelajaran ini semakin berkembang dengan kemajuan teknologi yang ada saat ini, seperti akses internet serta software pendukung lainnya (Susanti \& Hamama Pitra, 2019). Pada pembelajaran konvensional guru menyampaikan materi, kemudian untuk menambah pemahaman materi tersebut maka peserta didik mengerjakan tugas di sekolah dan akan diberikan pekerjaan rumah oleh guru. Pada model pembelajaran flipped classroom ini peserta didik ikut serta dalam mempersiapkan pembelajaran melalui tontonan video, memahami powerpoint dan mengakses sumber belajar yang diberikan oleh guru baik berupa media online seperti e-learning. (Susanti \& Hamama Pitra, 2019).

Berdasarkan pengamatan yang dilakukan peneliti selama di SMP Negeri 2 Bontang. Pada masa pandemi, sekolah SMP Negeri 2 Bontang memaksimalkan menggunakan teknologi yang telah ada. Guru dan murid di SMP Negeri 2 Bontang menggunakan Telegram dan Google Classroom sebagai salah satu aplikasi yang digunakan untuk mengajar dan belajar. Tetapi hal itu kurang efektif dikarenakan beberapa siswa tidak ikut serta dalam proses pembelajaran dan tidak akifnya siswa dalam proses pembelajaran sehingga terdapat saran dari guru SMP Negeri 2 Bontang untuk mencoba menggunakan aplikasi zoom. Dalam wawancara kepada beberapa siswa, terkadang guru-guru hanya memberikan tugas kepada siswa tanpa memberikan materi/bahan ajar maupun menerangkannya sehingga siswa mengalami kesulitan dalam proses belajar dan menjawab soal. Maka dari itu peneliti mencari alternatif lain dengan menggunakan berbagai jenis aplikasi dan model pembelajaran sehingga mereka bisa dapat menyampaikan materi tanpa terputus-putus. Maka dari itu peneliti memilih model pembelajaran flipped classroom dan memilih aplikasi zoom sebagai media pembelajaran yang dilakukan. Siswa yang biasanya mendapatkan materi ketika pembelajaran berlangsung, ketika menggunakan model pembelajaran flipped classroom ini siswa lebih dulu akan diberikan berbagai materi atau bahan ajar sebelum hari proses pembelajaran dilaksanakn agar siswa bisa membaca, memahami, dan siap untuk mengikuti proses pembelajaran datang. Dalam model pembelajaran siswa juga akan mengerjakan tugas secara langsung dengan pemantauan saya dan observer di zoom sehingga tidak ada alasan siswa untuk bertanya dan bekerja sama dalam mengerjakan tugas. Selain itu, saya memilih media plattform zoom agar siswa bisa lebih aktif dan memungkinkan siswa bisa lebih 
Analisis Keaktifan dan...

memahami materi yang peneliti ajarkan agar siswa tidak merasa bingung ketika akan melakukan pengerjaan soal.

Pelaksanaan proses pembelajaran di sekolah pada umumnya akan muncul berbagai masalah dimana mempengaruhi peserta didik untuk mencapai pendidikan dengan apa yang telah ditetapkan. Salah satu contoh masalah yang dihadapi dalam pembelajaran di sekolah ialah rendahnya keaktifan belajar siswa. Maka dari itu, keaktifan dan hasil belajar siswa dalam masa BDR (Belajar Dari Rumah) perlu diteliti lebih dalam karena terlihat ketika kegiatan belajar mengajar dimulai siswa lebih menonjolkan sikap tidak antusias pada pembelajaran yang sedang dilaksanakan. Karena dengan berkurangnya keaktifan siswa dalam mengikuti kegiatan proses belajar mengajar akan menjadikan prestasi hasil belajar siswa cenderung akan lebih menurun.

Berdasarkan latar belakang yang dikemukakan, dilihat dari permasalahan diatas, maka peneliti mengambil judul yaitu "Analisis Keaktifan dan Hasil Belajar Siswa Dengan Menggunakan Model Pembelajaran Flipped Classroom Melalui Aplikasi Zoom Pada Materi Suhu dan Kalor di SMP Negeri 2 Bontang".

\section{METODE}

Jenis penelitian yang digunakan dalam penelitian ini yaitu penelitian kuantitatif. Metode penelitian kuantitatif merupakan salah satu jenis penelitian yang spesifikasinya adalah sistematis, terencana, dan terstruktur dengan jelas sejak awal hingga pembuatan desain penelitiannya. Metode penelitian yang digunakan adalah pre-eksperimen, mempunyai ciri utama yaitu sampel yang digunakan untuk eksperimen diambil secara random dari populasi tertentu tanpa kelompok kontrol dengan rancangan one group pretest-posttes design. Penelitian ini akan di laksanakan di SMP Negeri 2 Bontang, bertempat di Jl. Karel Sasult,No. 09, Tanjung Laut, Tj. Laut Indah, Bontang Selatan, Kota Bontang, Kalimantan Timur 75321. Alasan penelitian ini dilaksanakan untuk mengetahui keaktifan dan hasil belajar siswa di SMP Negeri 2 Bontang dengan menggunakan model pembelajaran flipped classroom melalui aplikasi zoom. Waktu penelitian ini dilaksanakan pada semester genap tahun ajaran (2020/2021) yang dimulai pada bulan Februari 2021. Sampel yang digunakan dalam penelitian ini adalah siswa kelas VII A, dengan jumlah sampel 34 siswa.

Teknik pengumpulan data pada penelitian ini yaitu observasi dan tes. Keaktifan belajar siswa diobservasi melalui lembar observasi keaktifan belajar siswa yang berisikan indikator-indikator keaktifan yang harus dicapai siswa. Penilaian pada lembar observasi ini dengan menentukan persentase keaktifan setiap siswa. Persentase keaktifan siswa diperoleh dengan rumus sebagai berikut:

$$
\text { kriteria }=\frac{\text { jumlah skor yang diperoleh }}{\text { skor maksimum }} \times 100 \%
$$

Keterangan :

$$
\begin{array}{ll}
75 \%-100 \% & \text { : tinggi } \\
51 \%-74 \% & \text { : sedang } \\
25 \%-50 \% & \text { : rendah } \\
0 \%-24 \% & \text { : sangat rendah }
\end{array}
$$

(Suseno et al., 2017)

Kemudian hasil yang didapatkan digunakan untuk dapat mengetahui seberapa besar keaktifan peserta didik dalam mengikuti proses belajar dengan menggunakan model pembelajaran flipped classroom melalui aplikasi zoom. Analisis ini dilakukan pada instrumen lembar observasi dengan menggunakan tehnik deskriptif melalui prosentase. Kemudian untuk teknis analisis tes data yang akan dianalisis diperoleh dari hasil tes yang telah dikerjakan oleh siswa yang berjumlah 10 butir soal essay dan dilakukan perhitungan besarnya persentase kemampuan siswa dengan menggunakan uji $\mathrm{N}$-Gain. Uji gaint ternormalisasi ( $N$-Gain) dilakukan untuk mengetahui peningkatan hasil belajar kognitif siswa setelah diberikan perlakuan. Peningkatan ini diambil dari nilai pretest dan posttest yang didapatkan 
Analisis Keaktifan dan...

oleh siswa. Setelah itu data yang diperoleh akan diinput menggunakan Microsoft Excel. Perhitungan $\mathrm{N}$-Gain dapat dinyatakan pada rumus dibawah ini:

$$
N-\text { Gain }=\frac{\text { skor posttest }- \text { skor pretest }}{100-\text { skor pretest }} \times 100 \%
$$

(Suseno et al., 2017)

Hasil belajar yang diperoleh akan dilihat dengan menggunakan kriteria nilai $N$-Gain sebagai berikut:

Tabel 1 Kriteria N-Gain

\begin{tabular}{cc}
\hline Kriteria $N$-Gain & Keterangan \\
\hline$N$-Gain $>0,7$ & Tinggi \\
\hline $10,3 \leq N$-Gain $\leq 0,7$ & Sedang \\
\hline$N$-Gain $<0,3$ & Rendah \\
\hline
\end{tabular}

Hasil yang diperoleh kemudian akan dibandingkan pada Kriteria Ketuntasan Minimal (KKM) yang ada di sekolah tersebut. KKM hasil belajar pengetahuan sebesar 75 . Jika nilai individu siswa kurang dari 75 maka siswa belum tuntas dan bila nilai yang diperoleh sama atau lebih dari 75 maka siswa telah telah tuntas. Selanjutnya, dilakukan perhitungan golongan tingkat kemampuan kognitif peserta didik untuk dapat mengetahui golongan tingkat kemampuan kognitif peserta didik, penulis menggunakan klasifikasi nilai yaitu:

$$
\text { Persantase Ketuntasan Belajar }=\frac{\sum T B}{N} \times 100 \%
$$

Dengan Keterangan :

$\Sigma$ TB : Junlah siswa yang tuntas

$\mathrm{N}$ : Banyaknya siswa

Tabel 2 Klasifikasi Nilai

\begin{tabular}{cc}
\hline Angka & Kriteria \\
\hline $80 \% \leq P<100 \%$ & Sangat Tinggi \\
\hline $60 \% \leq P<80 \%$ & Tinggi \\
\hline $40 \% \leq P<60 \%$ & Cukup \\
\hline $20 \% \leq P<40 \%$ & Rendah \\
\hline $0 \% \leq P<20 \%$ & Sangat Rendah \\
\hline
\end{tabular}

(Mulyani \& Muhtadi, 2019)

\section{HASIL DAN PEMBAHASAN}

HASIL

Berdasarkan hasil penelitian diperoleh data sebagai berikut :

\section{Keaktifan Siswa}

Hasil observasi keaktifan siswa berdasarkan indikator-indikator pada pertemuan pertama dengan menggunakan model pembelajaran flipped classroom dari 34 siswa terdapat 8 siswa yang kriteria keaktifannya tinggi, 10 siswa kriteria keaktifan sedang, 6 siswa kriteria keaktifan rendah, dan 10 siswa dengan kriteria keaktifan sangat rendah. Rata-rata1keaktifan1siswa1kelas VII A adalah 57,77\% sehingga termasuk dalam kriteria sedang.

Tabel 3 Kriteria Keaktifan Siswa Pada Pertemuan Pertama

\begin{tabular}{cc}
\hline Jumlah siswa & Kriteria Keaktifan \\
\hline 8 & Tinggi \\
\hline 10 & Sedang \\
\hline 6 & Rendah \\
\hline 10 & Sangat rendah \\
\hline \multicolumn{2}{c}{ Total 34 siswa } \\
\hline
\end{tabular}


Analisis Keaktifan dan...

Hasil observasi keaktifan siswa pada pertemuan kedua dengan menggunakan model pembelajaran flipped classroom dari 34 siswa terdapat 4 siswa yang kriteria keaktifannya tinggi, 15 siswa kriteria keaktifan sedang, 6 siswa kriteria keaktifan rendah, dan 9 siswa dengan kriteria keaktifan sangat rendah. Rata-rata keaktifan siswa kelas VII A adalah $62 \%$ sehingga termasuk dalam kriteria sedang.

\begin{tabular}{|c|c|}
\hline Jumlah siswa & Kriteria Keaktifan \\
\hline 4 & Tinggi \\
\hline 15 & Sedang \\
\hline 6 & Rendah \\
\hline 9 & Sangat rendah \\
\hline \multicolumn{2}{|c|}{ Total 34 siswa } \\
\hline
\end{tabular}

Hasil observasi keaktifan siswa pada pertemuan ketiga dengan menggunakan model pembelajaran flipped classroom dari 34 siswa terdapat 14 siswa yang kriteria1keaktifannya tinggi, 14 siswa kriteria keaktifan sedang, 0 siswa kriteria keaktifan rendah, dan 6 siswa dengan kriteria keaktifan sangat rendah. Rata-rata keaktifan siswa kelas VII A adalah $75 \%$ sehingga termasuk dalam kriteria tinggi.

\begin{tabular}{cc}
$\begin{array}{c}\text { Tabel } 5 \text { Kriteria Keaktifan Siswa Pada Pertemuan Ke } \\
\text { Jumlah siswa }\end{array}$ & Kriteria Keaktifan \\
\hline 14 & Tinggi \\
\hline 14 & Sedang \\
\hline 0 & Rendah \\
\hline 6 & Sangat rendah \\
\hline \multicolumn{2}{c}{ Total 34 siswa } \\
\hline
\end{tabular}

\section{Hasil Belajar}

Data hasil belajar didapatkan pada kegiatan posttest dengan menggunakan soal tes berupa soal uraian sebanyak 10 butir soal. Penilaian ini dilakukan setelah pembelajaran menggunakan flipped classroom dilakukan sebanyak empat kalipertemuan. Hasil nilai posttest dibandingkan dengan nilai pretest menggunakan rumus $\mathrm{N}$-Gain untuk mengetahui tingkat keefektifan flipped classroom dalam meningkatkan hasil belajar siswa.

Berdasarkan perhitungan yang didapat nilai $\mathrm{N}$-Gain adalah 0,56 . Jika dibandingkan dengan tabl kriteria keefektifan, maka nilai $\mathrm{n}$-gain pada penelitian ini termasuk dalam kategori sedang. Siswa dinyatakan tuntas apabila siswa mencapai kriteria KKM yang telah ditetapkan yaitu 75 . Perbandingan tingkat kelulusan dengan mengacu nilai pretest dan1nilai postest dapat dilihat pada tabel dibawah ini.

Tabel 6 Perbandingan Kelulusan Siswa Pada Saat Pretest dan Posttest

\begin{tabular}{lcc}
\multirow{2}{*}{$\begin{array}{l}\text { Kriteria } \\
\text { Kelulusan }\end{array}$} & \multicolumn{2}{c}{ Jumlah siswa } \\
\cline { 2 - 3 } & Pretest & Posttest \\
\hline Lulus & 1 & 17 \\
\hline Tidak Lulus & 33 & 17 \\
\hline
\end{tabular}

Berdasarkan tabel 6 di atas dapat diketahui bahwa jumlah siswa yang melebihi kriteria ketuntasan minimal pada saat posttest lebih banyak dibandingkan pada saat pretest. Hal ini mendukung temuan penelitian bahwa penggunaan flipped classroom dapat meningkatkan hasil belajar siswa. Selain didukung dengan data sisw yang lulus, keefektifan penggunaan flipped classroom juga didukung oleh data nilai maksimal dan minimal siswa ketikaa pre-test dan post-test. Data nilai maksimal dan nilai minimal siswa dapat dilihat dibawah ini: 
Analisis Keaktifan dan...

Tabel 7 Perbandingan Nilai Pretest dan Posttest

\begin{tabular}{ccc} 
Nilai & Pretest & Posttest \\
\hline Maksimal & 75 & 95 \\
\hline Minimal & 5 & 60 \\
\hline
\end{tabular}

Berdasarkan analisis data yang telah dilakukan, dapat dinyatakann bahwa penggunaan flipped classroom terbukti dapat meningkatkan hasil belajar siswa dengan tingkat efektivitas sedang.

\section{Kemampuan Kognitif Peserta Didik}

Kemampuan kognitif siswa dapat di deskripsikan sebagai berikut:

1. Deskripsi kemampuan kognitif peserta didik pada tingkat mengingat (C1).

Tabel 8 Kemampuan Kognitif Siswa Pada Tingkat Mengingat (C1)

\begin{tabular}{cc} 
Keterangan & Nomor Soal \\
\cline { 2 - 2 } & 1 \\
\hline Jumlah jawaban benar & 22 \\
\hline Total jawaban benar & 22 \\
\hline Total jawaban keseluruhan & 23 \\
\hline Persentase & $95 \%$
\end{tabular}

Berdasarkan tabel 8 jelas terlihat bahwa hampir seluruh peserta didik dapat menyelesaikan tiap soal pada tingkatan mengingat (C1). Untuk tingkat mengingat (C1) memiliki persentase sebesar $95 \%$. Soal untuk tingkat $\mathrm{C} 1$ berjumlah 1 soal. Peserta didik yang mampu menjawab soal nomor 1 sebanyak 22 siswa.

2. Deskripsi kemampuan kognitif siswa pada tingkat memahami (C2)

Tabel 9 Kemampuan Kognitif Siswa Pada Tingkat Memahami (C2)

\begin{tabular}{cccc}
\hline Keterangan & \multicolumn{3}{c}{ Nomor Soal } \\
\cline { 2 - 4 } & 2 & 3 & 22 \\
\hline Jumlah jawaban benar & 23 & 23 & \\
\hline Total jawaban benar & & 68 & \\
\hline Total jawaban keseluruhan & 69 & \\
\hline Persentase & $98 \%$ &
\end{tabular}

Berdasarkan tabel 9 jelas terlihat bahwa hampir seluruh peserta didik dapat menyelesaikan tiap soal pada tingkatan memahami (C2). Untuk tingkat memahami (C2) memiliki persentase sebesar $98 \%$. Soal untuk tingkat $\mathrm{C} 2$ berjumlah 3 soal dengan nomor butir soal 2, 3, dan 4. Peserta didik yang bisa menjawab soal nomor 2 sebanyak 23 siswa, yang bisa menjawab soal nomor 3 sebanyak 23 siswa, dan yang mampu menjawab soal nomor 4 sebanyak 22 siswa.

3. Deskripsi kemampuan kognitif siswa pada tingkat menerapkan (C3)

Tabel 10 Kemampuan Kognitif Siswa Pada Tingkat Menerapkan (C3)

\begin{tabular}{cccc}
\hline Keterangan & \multicolumn{3}{c}{ Nomor Soal } \\
\cline { 2 - 4 } & 5 & 6 & 7 \\
\hline Jumlah jawaban benar & 14 & 10 & 14 \\
\hline Total jawaban benar & 38 & \\
\hline Total jawaban keseluruhan & 69 \\
\hline Persentase & $55 \%$
\end{tabular}

Berdasarkan tabel 10 jelas terlihat bahwa hampir keseluruhan peserta didik dapat menyelesaikan tiap soal pada tingkatan menerapkan (C3). Untuk tingkat menerapkan (C3) memiliki persentase sebesar $55 \%$. Soal untuk tingkat C3 berjumlah 3 soal dengan nomor butir soal 5, 6, dan 7 . Peserta didik 
yang bisa menjawab soal nomor 5 sebanyak 14 siswa, yang bisa menjawab soal nomor 6 sebanyak 10 siswa, dan yang bisa menjawab soal nomor 7 sebanyak 14 siswa.

4. Deskripsi kemampuan kognitif siswa pada tingkat menganalisis (C4)

Tabel 11 Kemampuan Kognitif Siswa Pada Tingkat Menganalisis (C4)

\begin{tabular}{cc}
\hline Keterangan & Nomor Soal \\
\cline { 2 - 2 } & 8 \\
\hline Jumlah jawaban benar & 12 \\
\hline Total jawaban benar & 12 \\
\hline Total jawaban keseluruhan & 23 \\
\hline Persentase & $52 \%$ \\
\hline
\end{tabular}

Berdasarkan tabel 11 jelas terlihat bahwa hampir keseluruhan peserta didik dapat menyelesaikan tiap soal pada tingkatan menganalisis (C4). Untuk tingkat menganalisis (C4) memiliki persentase sebesar $52 \%$. Soal untuk tingkat C4 berjumlah 1 soal dengan nomor butir soal 8 . Peserta didik yang mampu menjawab soal nomor 8 sebanyak 12 siswa.

5. Deskripsi kemampuan kognitif siswa pada tingkat mengevaluai (C5)

Tabel 12 Kemampuan Kognitif Siswa Pada Tingkat Mengevaluasi (C5)

\begin{tabular}{cccc} 
Keterangan & \multicolumn{3}{c}{ Nomor Soal } \\
\cline { 2 - 4 } & 9 & 10 \\
\hline Jumlah jawaban benar & 20 & 4 \\
\hline Total jawaban benar & & \\
\hline Total jawaban keseluruhan & 46 \\
\hline Persentase & $52 \%$
\end{tabular}

Berdasarkan tabel 12 jelas terlihat bahwa hampir keseluruhan peserta didik dapat menyelesaikan tiap soal pada tingkatan mengavaluasi (C5). Untuk tingkat mengevaluasi (C5) memiliki persentase sebesar $52 \%$. Soal untuk tingkat C5 berjumlah 2 soal dengan nomor butir soal 9 dan 10 . Siswa yang bisa menjawab soal nomor 9 sebanyak 24 siswa, dan siswa yang bisa menjawab soal nomor 10 sebanyak 4 siswa.

Berdasarkan data di atas, dapat kita lihat rata-rata kemampuan kognitif siswa di kelas VII A tingkat mengingat (C1), memahami (C2) dikategorikan sangat tinggi, sedangkan padatingkat menerapkan (C3), menganalisis (C4), mengevaluasi (C5) dikategorikan cukup. Hal ini dapat dilihat dalam grafik.

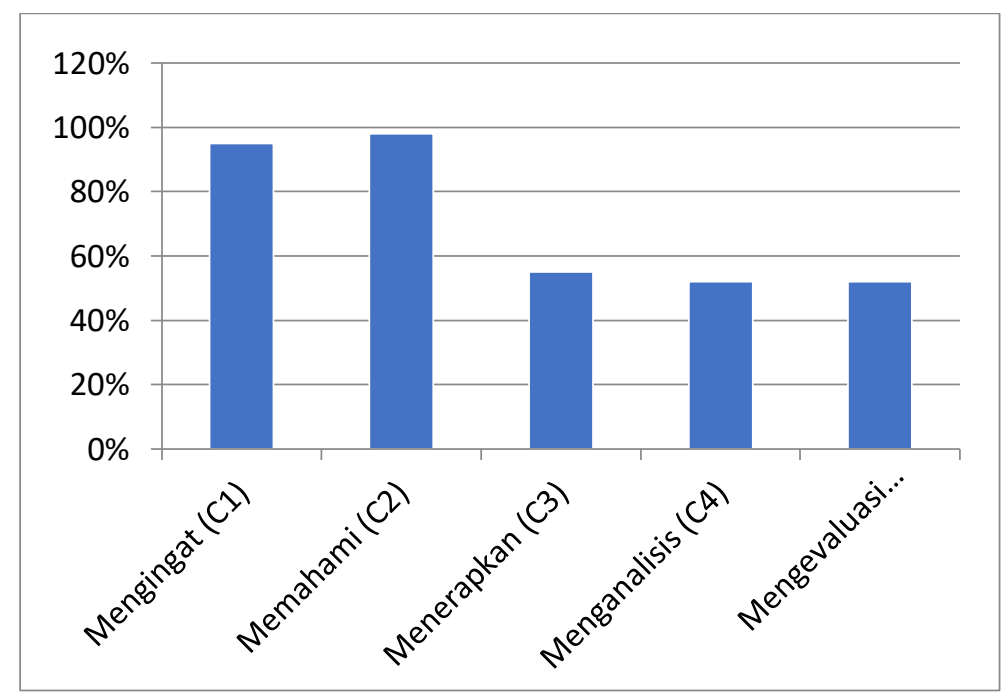

Gambar 1 Hasil Analisis Kemampuan Kognitif Peserta Didik 
Analisis Keaktifan dan...

\section{PEMBAHASAN}

\section{Keaktifan Siswa}

Keaktifan siswa merupakan keadaan dimana siswa dapat melakukan berbagai kegiatan yang aktif dimana siswa memiliki rasa cenderung memiliki rasa ketertarikan dan semangat yang dilakukan dengan dasar penting untuk keberhasilan proses pembelajaran dengan menggunakan indikatorindikator keaktifan. Indikator keaktifan siswa pada saat pembelajaran offline maupun online (daring) terdapat perbedaan, dimana pada saat pembelajaran offline (tatap muka) terdapat beberapa indikator keaktifan siswa yaitu siswa perhatian dalam penjelasan guru, mampu mengemukakan pendapat, aktif mengajukan pertanyaan, ikut serta mencari informasi untuk memecahkan permasalahan yang sedang dibahas dalam suatu materi, mampu menyimpulkan materi yang disampaikan, dan mengumpulkan tugas-tugas yang diberikan guru, siswa dapat bekerja sama dalam kelompok, memberi kesempatan berpendapat kepada teman dalam kelompok, berdiskusi, dan saling membantu dalam menyelesaikan masalah kelompok. Tetapi pada saat pembelajaran online (daring) berlangsung terdapat indikator yang tidak bisa dilaksanakan seperti berdiskusi sesama teman kelompok, kerjasama dalam kelompok, memberi kesempatan berpendapat kepada teman dalam kelompok, dan saling membantu dan menyelesaikan masalah dalam kelompok. Penilaian keaktifan siswa ini dilihat berdasarkan hasil observasi yang dilakukan selama tiga kali pertemuan pembelajaran dan dibantu oleh lima rekan obsever dalam proses pembelajaran.

Pada pertemuan pertama keaktifan siswa belum memenuhi indikator keberhasilan penelitian karena pada pertemuan pertama hanya1mencapai1persentase keaktifan siswa $57,77 \%$ dengan kriteria sedang. Beberapa faktor yang bisa menyebabkan sedangnya keaktifan siswa pada saat pembelajaran 1) ada beberapa siswa yang tidak ikut serta dalam pembelajaran, pada pertemuan pertama terdapat 7 siswa yang tidak ikut serta dalam melakukan proses pembelajaran, 2) banyak siswa yang tidak mengumpulkan tugas, 3) siswa belum mampu mengumpulkan tugas dengan tepat waktu, 4) siswa belum mampu memberikan pendapat terhadap pembelajaran, 5) siswa terkadang masih merasa malu1 bertanya jika materi yang dipelajari belum dimengerti, 6) siswa kurang aktif memperhatikan dan mendengarkan penjelasan dari guru. Kemudian, pada pertemuan kedua, keaktifan siswa belum memenuhi indikator keberhasilan penelitian juga dikarenakan pada pertemuan kedua hanya mencapai persentase keaktifan siswa $62 \%$ dengan kriteria sedang. Beberapa faktor-faktor yang dapat menyebabkan rendahnya keaktifan siswa pada saat pembelajaran 1) banyak siswa yang tidak ikut serta dalam pembelajaran, pada pertemuan kedua terdapat 8 siswa yang tidak ikut serta dalam melakukan proses penelajaran,. 2) beberapa siswa yang tidak mengunpulkan tugas, 3) siswa belum mampu mengumpulkan tugas dengan tepat waktu, 4) siswa belum mampu memberikan pendapat terhadap pembelajaran, 5) siswa terkadang masih merasa malu bertanya jika materi yang dipelajar belum dimengerti, 6) siswa kurang aktif memperhatikan dan mendengarkan penjelasan dari guru.

Keaktifan siswa pada pertemuan ketiga meningkat menjadi $75 \%$ dan termasuk kedalam kriteria keaktifan tinggi. Dengan ini dapa dikatakan telah memenuhi indikator-indikator keberhasilan. Hal ini dapat disebabkan dalam beberapa hal 1) siswa yang tidak hadir berkurang dari pertemuan satu dan pertmeuan dua, dimana pada pertemuan tiga siswa yang tidak hadir menjadi 6 siswa, 2) siswa telah mampu mengumpulkan tugas, 3) siswa telah berani untuk sesering mungkin mengemukakan pendapat dan bertanya hal yang belum dimengerti, 4) siswa memperhatikan penjelasan dari guru.

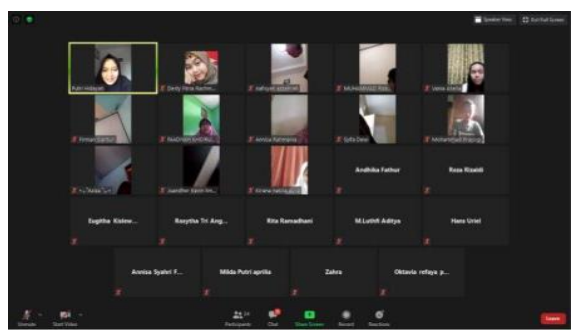

Gambar 2 Contoh indikator keaktifan siswa 1

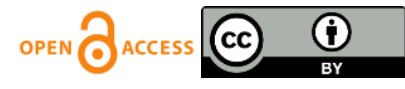




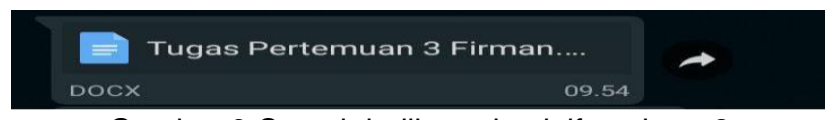

Gambar 3 Contoh indikator keaktifan siswa 2

Keaktifan siswa dalam proses belajar mengajar menggunakan beberapa indikator-indikator yang ada. Pada penelitian kali ini peneliti menggunakan 10 indikator pernyataan yaitu 1) Siswa mengikuti pelajaran atau masuk ke dalam aplikasi zoom, 2) Siswa aktif memperhatikan dan mendengarkan penjelasan dari guru, 3) Siswa mempelajari materi yang sudah diberikan sebelumnya, 4) Siswa mengajukan pertanyaan yang berhubungan dengan materi kepada guru, 5) Siswa dapat memberikan tanggapan sesuai dengan materi yang disampaikan, 6) Menggunakan media pembelajaran yang tersedia, 7) Siswa mencatat hal-hal penting yang disampaikan oleh guru ketika pembelajaran, 8 Siswa mengerjakan tugas atau latihan-latihan soal yang diberikan guru, 9) Siswa tepat waktu dalam mengumpulkan tugas, 10) Siswa berusaha mencari jawaban di buku/literatur lain untuk menyelesaikan tugas. Pada gambar 2 dan gambar 3 di atas terdapat salah satu contoh dari indikator keaktifan siswa yang berlangsung selama proses mengajar dimulai. Dimana pada gambar 2 termasuk ke dalam indikator siswa yaitu siswa mengikuti pelajaran atau masuk ke dalam aplikasi zoom. Jika siswa yang tidak mengikuti pelajaran dan tidak masuk ke dalam aplikasi zoom maka indikator siswa pada nomor tersebut tidak dinilai. Sedangkan pada gambar 3 termasuk ke dalam indikator siswa yaitu siswa-siswa mengerjakan tugas/latihan-latihan soal diberikan oleh guru. Jika siswa tidak mengikuti indikator tersebut maka indikator siswa pada nomor tersebut tidak dinilai.

\section{Hasil Belajar Siswa}

Meningkatnya keaktifan siswa ini juga berefek pada meningkatnya hasil belajar siswa. Hasil belajar sendiri merupakan nilai atau1skor1yang1diperoleh1siswa setelah mengikuti pembelajaran menggunakan model pembelajaran flipped classroom dalam materi suhu dan kalor. Berdasarkan analisis yang telah dilakukan diketahui bahwa jumlah siswa yang melewati batas KKM meningkat yang dari sebelumnya 1 siswa menjadi 17 siswa. Nilai maksimal yang dicapai siswa ketika posttest adalah 95 dan nilai minimalnya adalah 60 . Capaian tersebut lebih baik daripada capaian siswa ketika pretest, yaitu nilai maksimalnya adalah 75 dan nilai minimalnya adalah 5 .

Peningkatan hasil belajar siswa ini juga didukung dengan rata-rata nilai tugas siswa setiap pertemuan. Rata-rata1nilai1tugas siswa pada pertemuan pertama adalah sebesar 94,6, rata-rata nilai tugas pada pertemuan kedua adalah 95,88 dan rata-rata nilai tugas pada pertemuan ketiga adalah 97,4. Berdasarkan data-data tersebut dapat dilihat bahwa terjadinya peningkatan nilai hasil belajar setiap pertemuan ketika menggunakan flipped classroom. Level kognitif yang menjadi acuan pada soal posttest ini mengacu pada taksonomi bloom.

1. Mengingat (C1)

Kemampuan mengingat dapat diartikan sebagai kemampuan mengetahui tentang fakta, prinsip, dan konsep. Berdasarkan dari data yang diperoleh peserta didik untuk tingkat mengingat $(C 1)$ sebesar $95 \%$. Dari hasil penelitian ini terlihat bahwa kemampuan pesert didik pada tingkat mengingat (C1) dikategorikan sangat tinggi.

2. Memahami (C2)

Memahami merupakan kemampuan1seseorang untuk mengerti tentang sesuatu setelah diketahui dan diingat. Berdasarkan data diatas diperoleh hasil bahwa kemampuan kognitif peserta didik untuk tingat memahami (C2) sebesar 98\%. Dari hasil penelitian ni terlihat bahwa kemampuan peserta didik pada tingkat memahami (C2) dikategorikan sangat tinggi.

3. Menerapkan (C3)

Menerapkan adalah kemampuan seseorang untuk menerapkan atau menggunakan suatu prinsip, teori, ide, atau prosedur dalam situasi nyata. Berdasarkan data diatas diperoleh hasil bahwa kemampuan kognitif peserta didik untuk tingat menerapkan (C3) sebesar 55\%. Dari hasil 
penelitian ini terlihat bahwa kemampuan peserta didik pada tingkat menerapakan (C3) dikategorikan cukup.

4. Menganalisis (C4)

Menganalisis adalah kemampuan memecah-mecah materimenjadi bagian-bagian penyusunnya dan menentukan hubungan-hubungan antar bagian itu dan hubungan antara bagian-bagian tersebut dan keseluruhan struktur atau tujuan. Berdasarkan data diatas diperoleh hasil bahwa kemampuan kognitif peserta didik untuk tingat menganalisis (C4) sebesar $52 \%$. Dari hasil penelitian ini terlihat bahwa kemampuan peserta didik pada tingkat menganalisis (C4) dikategorikan cukup.

5. Mengevaluasi (C5)

Mengevaluasi merpakan kemampuan berpikir untuk dapat mengambil keputusan berdasarkan kriteria dan/atau standar tertentu. Berdasarkan data diatas diperoleh hasil bahwa kemampuan kognitif peserta didik untuk tingat mengevaluasi (C5) sebesar 52\%. Dari hasil penelitian ini terlihat bahwa kemampuan peserta didik pada tingkat mengevaluasi (C5) dikategorikan cukup.

\section{PENUTUP}

Berdasarkan dari hasil penelitian yang sudah dilakukan oleh peneliti dapat disimpulkan bahwa:

1. Keaktifan siswa dalam proses belajar mengajar dengan menggunakan model pembelajaran flipped classroom melalui aplikasi zooom dalam materi suhu dan kalor dilakukan selama melalui tiga pertemuan. Keaktifan siswa pada pertemuan pertama dan pertemuan kedua masih tergolong kedalam kriteria keaktifan siswa sedang. Pada pertemuan pertama keaktifan siswa hanya mencapai persentase $57,77 \%$ begitu juga dengan pertemuan kedua kriteria keaktifan siswa hanya mencapai persentase $62 \%$. Kemudian pada pertemuan ketiga keaktifan siswa termasuk kedalam kriteria keaktifan siswa tinggi dengan persentase $75 \%$. Dengan demikian dapat dikatakan telah memenuhi indikator keberhasilan penelitian.

2. Hasil belajar siswa dengan menggunakan model pembelajaran flipped classroom melalui aplikasi zoom dilakukan selama 4 kali pertemuan dengan materi suhu dan kalor. Berdasarkan perhitungan diketahui nilai $\mathrm{N}$-gain adalah 0,56 . Jika dibandingkan dengan tabel kriteria keefektifan, maka nilai n-gain penelitian ini termasuk kedalam kategori sedang dengan jumlah siswa yang melewati batas kriteria kelulusan minimal meningkat dari yang sebelumnya 1 siswa menjadi 17 siswa. Kemampuan kognitif siswa pada tingkat mengingat (C1), dan memahami (C2) sudah menunjukan sangat tinggi karena persentase yang di dapat sangat tinggi yaitu (95\%) dan (98\%). Sedangkan kemampuan kognitif siswa pada tingkat menerapkan (C3), menganalisis (C4), dan, mengevaluasi (C5)masih terbilang cukup karena persentase yang didapatkan yaitu (55\%), (52\%), dan (52\%).

\section{DAFTAR PUSTAKA}

Galindo, I. (2014). Flip Your Classroom: Reach Every Student in Every Class Every Day. By Jonathan Bergmann and Aaron Sams. Alexandria, Va.: The Association for Supervision and Curriculum Development, 2012. ix + 112 pages. ISBN 978-1-56484-315-9. 13.57. In Teaching Theology \& Religion (Vol. 17, Issue 1). https://doi.org/10.1111/teth.12165

Haqien, D., \& Rahman, A. A. (2020). Pemanfaatan Zoom Meeting untuk Proses Pembelajaran pada Masa Pandemi Covid-19. SAP (Susunan Artikel Pendidikan), 5(1). https://doi.org/10.30998/sap.v5i1.6511

Indah Utari Akip. (2019). Efektivitas Model Pembelajaran Flipped Classroom Dilengkapi Dengan Mind Mapping Terhadap Peamahaman Konsep Fisika Peserta Didik.

Mulyani, M., \& Muhtadi, D. (2019). Analisis Kesalahan Siswa Dalam Menyelesaikan Soal Trigonometri Tipe Higher Order Thinking Skill Ditinjau Dari Gender. Jurnal Penelitian Dan Pembelajaran Matematika, 12(1), 1-16. https://doi.org/10.30870/jppm.v12i1.4851

Nurkholis. (2013). Pendidikan Dalam Upaya Memajukan Teknologi Oleh: Nurkholis Doktor IImu Pendidikan, Alumnus Universitas Negeri Jakarta Dosen Luar Biasa Jurusan Tarbiyah STAIN 
Analisis Keaktifan dan...

Purwokerto.

Jurnal

Kependidikan,1(1),2444.http://ejournal.iainpurwokerto.ac.id/index.php/jurnalkependidikan/arti cle/ download/530/473/

Susanti, L., \& Hamama Pitra, D. A. (2019). Flipped Classroom Sebagai Strategi Pembelajaran Pada Era Digital. Health \& Medical Journal, 1(2), 54-58. https://doi.org/10.33854/heme.v1i2.242

Suseno, W., Yuwono, I., \& Muhsetyo, G. (2017). Persamaan Linear Dua Variabel Dengan Pembelajaran Kooperatif Tgt. Jurnal Pendidikan: Teori, Penelitian, Dan Pengembangan, 2(10), 1298-1307. http://journal.um.ac.id/index.php/jptpp/\%0AEISSN: 